\title{
MEMBINA KECERDASAN SPIRITUAL SISWA KELAS IV SD ALA GURU PAI
}

\section{Umi Sarwindah \& Chubbi Millatina Rokhuma*}

\begin{abstract}
Abstrak: Strategi merupakan salah satu unsur paling penting dalam ranah pendidikan. Terutama terkait erat dengan proses pembinaan kecerdasan spiritual siswa kelas IV SD. Dalam pembinaan kecerdasan spiritual siswa kelas IV SD seorang guru PAI dalam penyampaian materi-materi harus mempunyai sebuah strategi yang sesuai dan tepat karena dengan adanya sebuah strategi. Dengan strategi yang sesuai dan tepat diharapkan dapat membina kecerdasan spiritual siswa kelas IV SD $\mathrm{N}$ Juragan menjadi lebih baik. Penelitian ini menggunakan pendekatan kualitatif, dengan jenis penelitian lapangan (field research) adapun tempat penelitiannya yaitu di SD Negeri Juragan. Pengumpulan data dilakukan melalui observasi, wawancara dan dokumentasi. Adapun analisis datanya dilakukan secara deskriptif. Penelitian menunjukkan bahwa Strategi yang dilakukan guru PAI dalam membina kecerdasan spiritual siswa kelas IV SD N Juragan Kandeman mulai dari kurikulum tersembunyi sampai mengajak siswa menikmati keindahan alam berjalan dengan baik dan efektif, dimana anak-anak lebih mampu dan terbiasa menerima bimbingan kecerdasan spiritual sesuai dengan ajaran Islam. Siswa mulai mencerminkan kecerdasan spiritual yang telah terbina. Adapun faktor pendukung dan penghambat dari lingkungan keluarga, lingkungan masyarakat dan teman sebaya memang berdampak pada pembinaan kecerdasan spiritual siswa.
\end{abstract}

Kata kunci : Strategi guru PAI, Pembinaan kecerdasan spiritual, Kecerdasan spiritual kelas IV SD

* Alumni FTIK IAIN Pekalongan, Dosen FTIK IAIN Pekalongan Email: Umiindahwindah@gmail.com, Millatina2014@yahoo.com 


\section{Pendahuluan}

endidikan merupakan usaha yang dilakukan oleh seorang pendidik terhadap peserta didik agar tercapai perkembangan L maksimal yang positif (Tafsir, 2001: 28). Pendidikan memiliki peran penting dalam menciptakan manusia yang berkualitas dan bermartabat dalam kehidupan guna mencapai tujuan kehidupan yang baik. Dengan pendidikan peserta didik diharapkan mampu menjadi generasi yang mengharumkan nama bangsa tanpa meninggalkan norma-norma yang telah berlaku dalam masyarakat. Pendidikan yang mencakup segala aspek seperti pendidikan umum dan pendidikan agama. Pendidik atau guru yang menjadi unsur penting dalam pendidikan bagi peserta didik guna mencetak peserta didik yang berkualitas dan bermartabat.

Dalam pendidikan para orang tua mengharapkan anak-anak mereka dapat mencapai kesuksesan. Kesuksesan yang diharapkan para orang tua sudah tentu bukan hanya pada kemampuan umum yang mencakup kecerdasan intelektual. Di sisi lain para orang tua juga mengharapkan agar anak-anaknya mencapai kesuksesan dalam segi spiritual agar mereka mampu menjadi anak-anak yang bermartabat serta mencerminkan nilai-nilai yang baik.

Kecerdasan spiritual, Menurut Danah Zohar dan Marshal, yang dikutip oleh Purwa Atmaja Prawira dalam bukunya Psikologi Pendidikan dalam Perspektif Baru, bahwa kecerdasan spiritual dapat menumbuhkan fungsi manusiawi seseorang sehingga membuat mereka menjadi kreatif, luwes, berwawasan luas, spontan, dapat menghadapi perjuangan hidup, menghadapi kecemasan dan kekhawatiran, dapat menjembatani diri sendiri dan orang lain, serta menjadi lebih cerdas secara spiritual dalam beragama (Prawira, 2013: 167-168). Kecerdasan spiritual seseorang diartikan sebagai kemampuan seseorang yang memiliki kecakapan transenden serta kesadaran yang tinggi menjalani kehidupan, menggunakan sumbersumber spiritual untuk memecahkan permasalahan hidup dan berbudi luhur (Ibung, 2009: 12-13). Kecerdasan spiritual dinilai sebagai kecerdasan tertinggi yang memadukan kedua bentuk kecerdasan sebelumnya yakni kecerdasan intelektual dan 
kecerdasan emisonal. Kecerdasan spiritual dinilai sebagai kecerdasan tertinggi karena merupakan jalan untuk bisa merasakan sebuah kebahagiaan (Ibung, 2009: 12-13).

Bagi seorang guru, khususnya guru agama Islam, bagi mereka aspek spiritualitas merupakan aspek penting yang perlu untuk dibina. Hal ini dikarenakan tugas seorang guru agama bukan hanya sekedar menyampaikan materi kepada siswanya, akan tetapi juga membimbing peserta didik agar tidak terjerumus kedalam hal negatif, yaitu dengan membina kecerdasan spiritual sehingga peserta didik mampu membawa diri mereka kedalam hal positif.

Dari survei yang peneliti lakukan di SD N Juragan dengan wawancara kepada salah satu peserta didik SD N Juragan kelas IV dengan nama Dini Wulandari (10), penulis menemukan keadaan peserta didik di tempat penelitian dimana kecerdasan spiritual anak cenderung biasa dan butuh bimbingan serta arahan, misalnya dalam hal sholat dhuhur berjamaah di sekolah peserta didik masih banyak yang bergurau saat melaksanakan ibadah sholat dhuhur berjamaah, selain itu saat mereka makan dan minum beberapa dari mereka masih tampak menggunakan tangan kiri, ada juga dari mereka yang masih suka bergurau saat guru menyampaiakan pembelajaran, serta saat ditanya ketika hendak berangkat sekolah, beberapa dari mereka masih banyak yang tidak berpamitan dengan orang tua mereka. Berdasarkan latar belakang masalah di atas maka penulis menguraikan rumusan masalah sebagai berikut: Bagaimana strategi guru PAI dalam membina kecerdasan spiritual siswa kelas IV SD N Juragan Kandeman Batang, Apa saja faktor-faktor yang mendukung dan menghambat guru PAI dalam membina kecerdasan spiritual siswa kelas IV SD N Juragan Kandeman Batang?. Berdasarkan rumusan masalah di atas, maka ada beberapa tujuan penelitian yang hendak dicapai. Adapun tujuan penelitian ini adalah sebagai berikut: Untuk mendiskripsikan strategi guru PAI dalam membina kecerdasan spiritual siswa kelas IV SD N Juragan Kandeman Batang, Untuk mendiskripsikan faktor-faktor apa saja yang mendukung dan menghambat guru PAI dalam membina 
kecerdasan spiritual siswa kelas IV SD N Juragan Kandeman Batang.

Berdasarkan penelusuran dan pengetahuan peneliti, terdapat beberapa penelitian serta kajian yang telah dilakukan terkait dengan peran guru PAI dan kecerdasan spiritual. Namun terdapat perbedaan baik dari lokasi maupun konsen penelitian ini dengan penelitian sebelumnya. Penelitian sebelumnya ataupenelitian terdahulu digunakan oleh penulisa dalam artikel ini untuk memperkaya data saja. Selian itu, penelitian terdahulu juga memperkaya bacaan penulis.

\section{Metode Penelitian}

Jenis penelitian yang dilakukan adalah penelitian lapangan (Field Research) yaitu penelitian yang dilakukan di kancah atau tempat terjadinya gejala-gejala yang diselidiki (Arikunto, 2003: 63). Peneliti ingin mengetahui secara langsung bagaimana keadaan tempat atau kancah yang dijadikan penelitian. Penelitian ini menggunakan pendekatan kualitatif. Yang merupakan pendekatan fenomena yang merupakan turunan filosofi fenomenologi. Oleh karena itu, jenis pendekatan dalam penelitian ini adalah menggunakan pendekatan kualitatif yaitu lebih menekankan pada analisisnya pada proses penyimpulan deduktif dan induktif serta analisis terhadap dinamika hubungan antara fenomena yang diamati dengan menggunakan logika ilmiah (Azwar, 1999: 5). Alasan penulis memilih jenis penelitian ini karena data yang diperoleh bersifat deskriptif dan dinamis dalam arti data itu tidak tetap dan dapat berubah sesuai kondisi yang sedang berlangsung. Pendekatan ini dilakukan secara wajar dan natural sesuai dengan kondisi objektif di lapangan tanpa adanya manipulasi (Arifin, 2011: 140). Yang menghasilkan data deskriptif yang berupa kata-kata tertulis atau lisan dari orang-orang yang diamati (Arikunto, 2005: 234). Sumber data dari penelitian adalah subyek asal data dapat diperoleh. Sumber data penelitian merupakan faktor penting yang menjadi pertimbangan dalam menentukan metode penulisan data, sumber data merupakan sumber yang diperoleh untuk mengumpulkan data yang kita 
perlukan dalam penelitian (Sangadji dan Sopiah, 2010: 169). Sumber data premier dan sumber data sekunder meliputi: Sumber data premier merupakan sumber data yang diperolah secara langsung dari objek penelitian sebagai sumber informasi yang di cari. Menurut Lexy J. Moleong, sumber data primer dalam penelitian kaulitatif adalah "kata-kata" dan "tindakan" (Moleong, 2006: 112). Berkaitan dengan sumber data primer, maka dalam penelitian ini yang termasuk adalah Guru PAI dan siswa kelas IV di SD N Juragan Kandeman Batang. Sumber data sekunder adalah sumber data yang tidak langsung memberikan data kepada pengumpul data, biasanya melalui dokumen atau arsip (Ghony \& Fauzan Almanshur, 2012: 164). Berkaitan dengan sumber data sekunder yang termasuk adalah dokumen atau arsip-arsip dan halhal yang relevan yang ada di SD N Juragan Kandeman Batang.

Adapun teknik pengumpulan data yang penulis gunakan dengan beberapa metode. Ada tiga metode teknik pengumpulan data yang di gunakan yaitu: Metode observasi ini menggunakan pengamatan atau penginderaan langsung terhadap suatu benda, kondisi, situasi, proses atau perilaku. Misalnya luas ruangan, keadaan ventilasi, jenis lantai ruangan, keadaan penerangan/lampu ruangan, dan jenis perabot apa saja yang tersedia dalam ruangan, sesmuanya dapat diperoleh dan dikumpulkan datanya bermacammacam benda, kondisi, situasi, proses, aktivitas, dan perilaku dapat diperoleh dan dikumpulkan datanya melalui penggunaan metode observasi (Faisal, 2010: 52). Metode ini digunakan untuk memperoleh data tentang strategi guru PAI dalam membina kecerdasan spiritual siswa di SD N Juaragan Kandeman Batang. Metode Wawancara, adalah percakapan dua orang atau lebih yang diajukan oleh peneliti kepada penelitian untuk dijawab (Danim, 2002: 30). Metode wawancara ini digunakan peneliti untuk mengadakan wawancara secara mendalam kepada guru Pendidikan Agama Islam dan juga peserta didik untuk menggali keterangan yang lebih mendalam tentang strategi guru PAI dalam membina kecerdasan spiritual siswa di SD N Juragan Kendeman Batang. Metode Dokumentasi, adalah mencari data mengenai hal-hal atau 
variabel yang berupa catatan, transkrip, buku,surat kabar, majalah, prasasti, notulen rapat, legger, agenda dan sebagainya (Arikunto, 2005: 236). Metode ini peneliti gunakan untuk memperoleh datadata tentang keadaan umum SD N Juragan Kandeman Batang, keadaan guru, siswa dan sarana prasarana. Analisis data merupakan proses mencari dan mengatur secara sistematis transkrip wawancara, catatan lapangan, dan bahan-bahan lain yang telah dihimpun untuk memperoleh pengetahuan dan pengalaman mengenai data tersebut. Berhubung penelitian ini berupa penelitian kualitatif maka aktivitas dalam analisis data dilakukan secara interaktif dan berlangsung secara terus menerus sampai tuntas, dengan langkah mereduksi data, penyajian data, penarikan kesimpulan dan verifikasi. Mereduksi data berarti merangkum, memilih hal-hal yang pokok, memfokuskan pada hal-hal yang penting, dicari tema dan polanya yang berkaitan dengan data kecerdasan spiritual. Setelah data direduksi, langkah selanjutnya adalah penyajian data, langkah ini dimaksudkan untuk menemukan suatu makna dari data-data yang diperoleh, kemudian disusun secara sistematis, dengan hal tersebut, maka akan memudahkan untuk memahami apa yang terjadi, merencanakan kerja selanjutnya berdasarkan apa yang telah dipahami tersebut. Langkah selanjutnya adalah penarikan kesimpulan dan verifikasi, sehinggga dengan hal tersebut dapat menggambarkan suatu pola tentang peristiwa yang terjadi (Sugiyono, 2014: 246-252).

\section{Hasil dan Pembahasan}

Guru Pendidikan Agama Islam secara etimologi (harfiah) dalam literatur kependidikan islam seorang guru biasa disebut sebagai ustadz, mu'alim, murabbi, mursyid, mudarris, dan muaddib, yang berarti orang yang memberikan ilmu pengetahuan dengan tujuan mencerdaskan dan membina akhlak peserta didik supaya menjadi orang yang berkepribadian baik (Muhaimin, 2005: 44-49). Guru (Pendidik) Sebagaimana dalam UUSPN No. 20 Tahun 2003, Bab 1, Pasal 1, Ayat 6 yaitu tenaga kependidikan yang berkaulifikasi sebagai guru, dosen, konselor, pamong belajar, widyaiswara, tutor, 
instruktur, fasilitator, dan sebutan lain yang sesuai dengan kekhususannya (UURI, 2003: 3). Menurut Undang-Undang Republik Indonesia Nomor 14 tahun 2005 mengenai Guru dan Dosen, Pasal 1, Ayat 1, Guru adalah pendidik profesional dengan tugas utama medidik, mengajar, membimbing, mengarahkan, melatih, menilai dan mengevaluasi peserta didik pada pendidikan anak usia dini pada jalur pendidikan formal, pendidikan dasar, dan pendidikan menengah (UURI, 2003: 2). Menurut Abdurrahman yang dikutip Ramayulis dalam bukunya yang berjudul Ilmu Pendidikan Islam, guru adalah anggota masyarakat yang berkompeten (cakap, mampu, dan mempunyai wewenang) dan memperoleh kepercayaan dari masyarakat atau pemerintah untuk melaksanakan tugas, fungsi peran serta tanggung jawabnya baik di lembaga formal maupun nonformal" (Ramayulis, 2008: 85-86). Menurut Syaiful Bahri Djamarah, guru adalah unsur manusiawi dalam pendidikan yang merupakan figur manusia sumber yang menempati posisi dan memegang peranan penting dalam pendidikan. Dalam hal ini secara sederhana yang dinamakan guru ialah orang yang memberikan ilmu pengetahuan kepada peserta didik" (Djamarah, 2000: 31). Sedangkan guru agama, Menurut H.M Arifin adalah hamba Allah yang mempunyai cita-cita islami, yang telah matang rohaniah dan jasmaniah serta memahami kebutuhan perkembangan siswa bagi kehidupan masa depannya, ia tidak hanya mentransfer ilmu pegetahuan tetapi memberikan nilai dan tata aturan yang bersifat islami ke dalam pribadi siswa sehingga mereka berperilaku bernafaskan Islam" (Arifin, 1996: 193). Guru dalam hal ini merupakan guru spiritual bagi seorang murid dengan maksud memberikan santapan rohani berupa pedidikan akhlak dan budi pekerti yang luhur (Al-Abrosy: 136). Adapun Pendidikan Agama Islam menurut Ahmadi, pendidikan agama islam adalah berbagai cara untuk menjaga dan mengembangkan fitrah manusia juga sumber daya yang ada padanya guna membentuk manusia seutuhnya (insan kamil) sesuai dengan norma agama Islam" (Achmadi, 2005: 28-29). Sedangkan menurut Masarudin Siregar, pedidikan agama Islam adalah upaya sadar untuk mempersiapkan 
peserta didik dalam mempercayai, mengerti dan mengamalkan agama islam dengan kegiatan pembinaan, pembelajaran, dan mempraktikan tuntutan untuk menghormati serta menghargai agama lain dalam hubungan kerukunan antar umat dalam masyarakat untuk mewujudkan persatuan nasional". (Siregar, 2000: 25)

Dari beberapa definisi di atas, dapat disimpulkan bahwa pengertian Guru Pendidikan Agama Islam, ialah seorang pendidik yang mengajarkan ajaran agama islam dan membimbing anak didik ke arah pencapaian kedewasaan juga membentuk kepribadian muslim yang berakhlak, yang menjadikan kebahagiaan di dunia dan akhirat.

Kecerdasan berasal dari kata "Cerdas" yang artinya sempurna perkembangan akal budinya yang hanya dimiliki oleh manusia (Wahab, 2004: 179). Sedangkan Flyn mendefinisikan kecerdasan sebagai kemampuan untuk berfikir secara abstrak dan kesiapan menerima belajar dari pengalaman (Azwar, 1996: 7). Sedangkan spiritual secara etimologi meurut Toy Buzta yang dikutip Agus Efendi, Spiritual berasal dari bahasa latin "Spiritus" artinya napas. Dalam dunia modern kata napas mengacu pada diri manusia yang bukan fisik, termasuk emosi dan karakter (Efendi, 2005: 206). Selanjutnya spiritual berarti sesuatu diluar tubuh fisik. Termasuk fikiran, perasaan, dan karakter seseorang. Kecerdasan spiritual atau spiritual Quotient (SQ). Kecerdasan ini adalah kecerdasan yang mengangkat fungsi jiwa sebagai perangkat internal diri yang memiliki kemampuan dan kepekaan dalam melihat makna yang ada dibalik sebuah kenyataan atau kejadian tertentu. Menurut Danah Zohar, yang dikutip Akhmad Muhaimin Azzet, Kecerdasan spiritual dinilai sebagai kecerdasan tertinggi karena erat kaitannya dengan kesadaran seseorang untuk bisa memaknai segala sesuatu dan merupakan jalan untuk bisa merasakan sebuah kebahagiaan (Azzet, 2013: 27). Menurut Marshal dan Danah Zohar, menempatkan bahwa kecerdasan spiritual sebagai aspek ketiga dari aspek sebelumnya (IQ dan EQ) yang merupakan pengenalan diri tanpa adanya campur tangan panca indra dan dunia luar yang 
membentuk kesadaran sejati manusia (Pasiak, 2003: 27). Kecerdasan spiritual seseorang diartikan sebagai kemampuan seseorang yang memiliki kecakapan transenden, kesadaran, yang tertinggi untuk menajalani kehidupan, menggunakan sumbersumber spiritual untuk memecahkan permasalahan hidup, dan berbudi luhur. Ia mampu berubungan baik dengan Tuhan dan Makhluknya (Siswanto, 2010: 11). Kecerdasan spiritual juga diartikan sebagai kemampuan dalam memberi makna. Dalam kondisi yang sangat buruk dan tidak diharapkan, kecerdasan spiritual mampu menuntun manusia untuk menemukan makna. Manusia dapat memberi makna melalui beberapa macam keyakinan, karena manusia dapat merasa memiliki makna dari berbagai hal. Agama mengarahkan manusia untuk mencari makna dengan pandangan yang lebih bermakna di hadapan Tuhan (Kurniasih, 2010: 28). Kecerdasan spiritual dapat juga diartikan kecerdasan ruhaniah karena kecerdasan ini didasarkan oleh hati nurani dan hati nurani bersumber dari Qolbu, didalamnya terdapat perasaan moral. Sehingga kualitas Qolbu akan menentukan apakah dirinya pantas sebagai subjek, atau bahkan wakil tuhan di bumi (Tasmara, 2001: 46-47).

Kecerdasan spiritual sangat erat kaitannya dengan kesadaran spiritual dalam diri individu, karena itu Marsa Sinetar menyebutnya sebagai kesadaran diri dimana individu bersama dengan kesadaran kemanapun kesadaran membawanya. Kecerdasan spiritual ini merupakan kecerdasan makna atau hakikat kehidupan ini sesuai dengan kodrat manusia sebagai makhluk Tuhan Yang Maha Esa yang wajib melaksanakan perintahnya dan menjauhi larangannya (Safaria, 2007: 16). Kecerdasan spiritual menumbuhkan spiritualitas yang sehat karena keduanya merupakan suatu kesatuan yang berkaitan. Orang yang cerdas secara spiritual merupakan orang yang sehat secara spiritual. Proses pembentukan dan pengembangan kecerdasan spiritual dilakukan sejak anak lahir hingga dewasa. Semakin dini proses ini dilakukan, maka akan semakin optimal hasil yang akan diperoleh(Safaria, 2007: 35). 
Menurut Desmita ada beberapa strategi yang dapat dilakukan guru dalam membantu mengembangkan spiritualitas peserta didik. memberikan pendidikan keagamaan melalui kurikulum tersembunyi, menjadikan pendidikan tempat yang kondusif untuk peserta didik dalam menghayati agamanya, tidak sekedar teoritis tetapi yang benar-benar dicontohkan dari pengalaman kebergamaan, membantu peserta didik dengan melalui pendekatan spiritual parenting, seperti: melalui doa setiap hari, mengajarkan anak untuk melibatkan Tuhan disetiap aktivitasnya, mengajarkan anak bahwa Tuhan akan membantu kita, mengajak anak merenungkan adanya Tuhan (Desmita, 2010: 286-287). Strategi guru dalam menumbuhkan kecerdasan spiritual pada siswa di sekolah dari penelitian yang dilakukan Atika Fitria dan Eka Yanuarti, diantaranya: Menjadi teladan bagi siswa dalam meningkatkan kecerdasan spiritual siswa, guru hendaknya mampu memberikan gambaran tentang pentingnya menanamkan kecerdasan spiritual dalam diri seseorang siswa. Membantu siswa merumuskan misi hidup mereka seperti halnya membantu siswa dalam mecari jalan untuk meraih kesuksesan di dunia dan di akhirat. Baca al-Qur`an bersama siswa dan jelaskan maknanya dalam kehidupan sehari-hari. Menceritakan pada siswa tentang kisah-kisah agung dari tokohtokoh spiritual, upaya ini merupakan komunikasi universal yang mampu dimanfaatkan guru pendidikan agama islam untuk membina kecerdasan spiritual siswa melalui petikan hikmah jalan hidup seorang tokoh panutan seperti kisah para Nabi dan Rasul, dan lain-lain. Mengajak siswa berdiskusi dalam berbagai persoalan dengan perspektif ruhaniah, pendekatan ini dinilai efektif untuk memberikan pemahaman kepada siswa untuk lebih bijak dalam menyikapi suatu persoalan, agar mereka bisa terhindar dari perbuatan yang terlarang dalam agama. Mengajak siswa kunjungan ke tempat-tempat orang sakit dan berta'ziah, dengan melakukan kunjungan seperti ini diharapkan siswa bisa memaknai dan mensyukuri nikmat yang diberikan oleh Allah SWT kepada mereka. Melibatkan siswa dalam kegiatan keagamaan, siswa akan didorong aktif mengerjakan kegiatan sehingga pekerjaan guru hanya sebagai 
fasilitator dan motivator siswa agar lebih disiplin melaksanakan ibadah atau kegiatan-kegiatan keagamaan lainnya. Dengan cara ini, siswa akan mudah dan cepat memahami tujuan dari kegiatan yang dilaksanakan itu, sehingga pembelajaran yang ia dapatkan akan benar-benar tertanam dalam diri siswa. Mengikutsertakan siswa dalam kegiatan-kegiatan sosial, kegiatan ini bertujuan agar siswa mengerti sebuah kerbersamaan, kesetiakawanan, kepedulian terhadap sesama sebagai makhluk ciptaan-Nya. Mengajak siswa menikmati keindahan alam, dengan adanya kegiatan ini diharapkan siswa lebih memahami tentang pencipta-Nya, dan akan mampu membawa mereka untuk selalu bersyukur atas nikmat dan karunia yang dititipkan oleh Allah SWT kepada mereka (Fitria dan Eka Yanuarti, 2018: 179-189). Faktor-faktor Kecerdasan Spiritual Kecerdasan spiritual perkembangannya dipengaruhi oleh beberapa faktor, antara lain:Lingkungan keluarga diperlukan hubungan yang harmonis, baik antara sesama anggota keluarga, maupun antara anggota keluarga dengan masyarakat. Dengan hubungan baik, maka akan terbina keluarga yang rukun dan damai. Berhasil atau tidaknya pendidikan di sekolah, tergantung pendidikan di keluarga. Pendidikan dalam keluarga adalah dasar dari pendidikan yang selanjutnya. Pendidikan dalam keluarga ditekankan pada pembinaan watak, karakter, kepribadian, dan ketrampilan mengerjakan pekerjaan atau tugas keseharian yang bisa terjadi di rumah tangga. Sebaliknya jika keluarga yang ada tidak baik maka pengaruhnya tidak baik (Nata, 2010: 191). Lingkungan masyarakat salah satu yang mempengaruhi perkembangan kecerdasan spiritual pada anak adalah pengaruh lingkungan masyarakat yang positif. Karena proses belajar anak pada lingkungan lebih banyak menggunakan proses meniru. Untuk itulah sangat perlu orang tua memiliki tempat tinggal pada lingkungan masyarakat yang bersih dari perbuatan melanggar nilai-nilai moral dan spiritual. Tempat tinggal yang cocok untuk anak adalah lingkungan masyarakat yang senantiasa menjunjung tinggi nilai-nilai moral, agama, dan spiritual yakni suatu tatanan masyarakat yang agamis atau masyarakat yang mampu membersihkan diri dari pengaruh hal-hal negatif. Sebaliknya jika 
lingkugan yang dipilih tidak baik maka pengaruhnya tidak baik (Safaria, 2007: 54). Teman sebaya pengaruh yang kuat juga ada pada teman sebaya. Terutama ketika anak memasuki usia remaja, dimana mereka akan lebih condong dan berorientasi sosial mengikuti pengaruh teman sebayanya. Pada saat remaja ini seorang anak memiliki tingkat rawan yang tinggi terjerumus dalam hal negatif. Untuk itulah sangat perlu bagi anak untuk memilih teman-teman sebayanya, jika anak memilih teman sebaya yang baik, maka pengaruhnya pada anak juga akan baik. Sebaliknya jika teman yang dipilih tidak baik maka pengaruhnya tidak baik (Safaria, 2007: 57).

Berdasarkan data yang diperoleh penerapan pembinaan kecerdasan spiritual siswa kelas IV SD Negeri juragan

\section{Penerapan Kurikulum Tersembunyi}

Penerapan kurikulum ini merupakan bentuk pembelajaran dalam rangka untuk memotivasi kecerdasan spiritual siswa, sehingga mereka dapat menerima khasanah-khasanah kehidupan dari materi pelajaran. Melalui observasi dan wawancara dengan narasumber yaitu Guru PAI SD N Juragan diperoleh keterangan bahwa penerapan kurikulum tersembunyi ini harus dilakukan dan banyak dilakukan guru PAI dalam membina kecerdasan spiritual siswa. Karena dengan penerapan kurikulum tersembunyi ini siswa akan merasa lebih diperhatikan oleh guru. Penerapan kurikulum tersembunyi ini lebih utama dilakukan ketika pembelajaran sedang berlangsung sehingga siswa lebih mampu menerima karena dalam keadaan konsentrasi ketika belajar di kelas. Penerapan kurikulum ini diawali dengan penyampaian materi biasa dan kemudian disampaikan khasanah-khasanah yang sesuai dengan kenyataan dalam kehidupan sehari-hari anak yang dapat dijadikan bekal kedepannya. Seperti ketika pembelajaran materi empati dan sabar, guru memberikan contoh nyata kepada para siswa. Ketika hendak berwudhu biasakan untuk mengantri karena dengan mengantri kita bisa memiliki sikap yang lebih sabar. Selain itu mengantri wudhu juga akan menumbuhkan rasa empati pada diri siswa karena dengan kegiatan tersbesut kita tidak merebut hak orang lain. Selain itu guru 
mencoba memberikan selipan khasanah dengan menceritakan kisah Nabi Muhammad yang memiliki sikap sabar dan empati, kisah Nabi yang selalu dihina oleh seorang pengemis buta namun beliau malah menolong perempuan tersebut dengan selalu memberinya makan. Hal tersebut senada degan pendapat Desmita yang mengatakan bahwa dalam membantu mengembangkan spiritualitas peserta didik, guru dapat memberikan pendidikan keagamaan melalui kurikulum tersembunyi (Desmita, 2010: 286-287). Pembinaan kecerdasan spiritual yang dilakukan melalui penerapan kurikulum tersembunyi untuk menjadikan siswa tidak melulu terpaku pada teori yang ada pada mata pelajaran, memberikan pecerahan bagi siswa dengan memberikan pesan-pesan yang baik agar dapat membimbing siswa ke dalam hal yang baik.

Dengan demikian, penarapan kurikulum tersembunyi merupakan bentuk strategi yang tepat bagi pembinaan kecerdasan spiritual siswa. Sebab dengan melakukan kurikulum tersembunyi ini anak akan terarah dan mudah menerima pengertian, nasihat, motivasi dan masukan dari guru dan orang lain.

\section{Guru Menjadi Teladan Bagi Siswa}

Menjadi teladan bagi siswa merupakan contoh nyata yang dilakukan seorang guru kepada siswanya yang dapat ditiru ketika berada dilingkungan sekolah. Dalam hal ini guru memberikan contoh perilaku yang mencerminkan kecerdasan spiritual yang baik bagi peserta didik. Dengan melakukan observasi dan wawancara dengan narasumber yaitu Guru PAI SD N Juragan didapat keterangan bahwa menjadi teladan bagi siswa adalah tuntutan bagi seorang guru yang merupakan figur penting dalam dunia pendidikan. Guru yang dikatakan di gugu lan ditiru menjadi salah satu alasan mengapa seorang guru harus mencerminkan sikap yang dapat membina kecerdasan spiritual siswa, salah satu hal yang dapat dilakukan guru ialah seperti berperilaku sopan dan santun ketika dilingkungan sekolah atau di luar sekolah. Hal tersebut sesuai dengan pendapat dari Atika Fitria dan Eka Yanuarti yang mengatakan menjadi teladan bagi siswa dalam meningkatkan 
kecerdasan spiritual siswa, guru hendaknya mampu memberikan gambaran tentang pentingnya menanamkan kecerdasan spiritual dalam diri seseorang siswa mereka (Fitria dan Eka Yanuarti, 2018: 179-189).

Dengan kata lain, perilaku teladan yang diterapkan guru sangat efektif untuk dilakukan. Sebab dalam pembinaan kecerdasan spiritual siswa mereka mendapat contoh secara langsung dari lingkungan sekitar terutama di sekolah. Dengan begitu anak merasa ada panutan yang baik ketika berada dilingkungan sekolah.

\section{Membantu Siswa Merumuskan Misi Hidup Mereka}

Dengan membantu misi hidup siswa maka akan terjadi tidak hanya kesuksessan dunia saja melainkan kesuksesan akhirat. Guru mampu meluruskan misi hidup mereka dengan mencoba memecahkan kendala ketika ada problem dalam kehidupan yang mampu menggoyahkan visi misi mereka. Dari hasil observasi dan wawancara dengan narasumber yaitu Guru PAI SD N Juragan diperoleh pejelasan bahwa guru mampu memberikan perhatian lebih kepada siswa, tidak hanya memberikan materi pendidikan secara formal melainkan guru juga dapat membantu merumuskan misi hidup siswa mereka, guru memcoba memberikan solusi bagi siswa mengenai problem yang dihadapi siswa. Dengan ini guru mengembalikan keadaan siswa kepada jalan yang lebih baik dengan memberikan arahan-arahan yang sesuai dengan problem dan usia mereka. Hal ini sesuai dengan pengungkapan Atika Fitria dan Eka Yanuarti bahwa guru selayaknya membantu siswa merumuskan misi hidup mereka seperti halnya membantu siswa dalam mecari jalan untuk meraih kesuksesan di dunia dan di akhirat (Fitria dan Eka Yanuarti, 2018: 179-189).

Dengan begitu dapat di katakan, hal ini sangat efektif memberikan pembinaan kecerdasan spiritual siswa. Sudah selayaknya guru memberikan ketenangan bagi siswa dengan memberikan solusi bagi problem yang menggangu visi misi hidup mereka. Guru harus terus menerus melakukan hal tersebut karena 
kehidupan setiap individu berbeda-beda, bisa jadi akan ada beberapa anak yang mengalaminya.

\section{Melakukan Baca Al-Qur'an Bersama dan Menjelaskan Maknanya}

Memberikan kebiasaan melaksanakan baca al-Qur'an bersama dan dijelaskan maknanya menjadi pendorong siswa berperilaku sesuai dengan ajaran agama islam melalui makna dalam ayat-ayat suci al-Qur'an. Oleh sebab itu penjelasan makna bagi siswa memberikan pengaruh baik kecerdasan spiritual mereka. Setelah dilakukan observasi dan wawancara dengan narasumber yaitu Guru PAI SD N Juragan diperoleh hasil bahwa guru melakukan kegiatan pembinaan dengan membaca al-Qur'an kemudian mejelaskan maknanya menjadi salah satu cara yang cukup baik. Karena dalam strategi ini guru mampu memberi ajaran kehidupan bagi peserta didik sebab dari berbagai ayat-ayat yang dibaca memberikan beberapa hal-hal yang menyangkut kehidupan sehari-hari peserta didik. Hal ini sependapat dengan yang disampaikan Atika Fitria dan Eka Yanuarti bahwa salah satu strategi yang dapat dilakukan guru dalam membina kecerdasan spiritual ialah Baca al-Qur an bersama siswa dan jelaskan maknanya dalam kehidupan sehari-hari (Fitria dan Eka Yanuarti, 2018: 179-189).

Oleh karena itu, selain memberikan pemaham kepada siswa mengenai makna dari ayat al-Qur'an yang berhubunga dengan kehidupan sehari-hari mereka hal ini juga agar dalam pembelajaran al-Qur'an tidak membosankan, dengan anak tahu makna tersebut diharapkan anak-anak lebih tertarik berlajar al-Qur'an. Ketertarikan siswa ini dapat menjadi cerminan langkah awal peserta didik mulai menampakan kecerdasan spiritual mereka.

\section{Menceritakan Kepada Siswa tentang Kisah-kisah Agung dari Para Tokoh-} tokoh Spiritual

Kisah-kisah yang menginspirasi menjadi suatu penyemangat secara tidak langsung bagi peserta didik. Kisah yang bisa saja menjadikan mereka memiliki gambaran bagaimana mereka kelak. Dari kegiatan observasi dan wawancara dengan narasumber yaitu 
Guru PAI SD N Juragan diperoleh hasil yang bahwa pengaruh kisah-kisah dari para tokoh ini berdampak baik bagi para siswa, guru mencoba menceritakan kisah-kisah para tokoh seperti nabi, para sahabat dan sebagainya secara berulang dan berganti-ganti dengan tujuan agar siswa lebih paham kisah yang diceritakan oleh guru. Guru mencoba menarik perhatian siswa dengan memberikan peluang anak-anak untuk tanya jawab, dengan begitu rasa penasaran akan terjawab. Kisah para tokoh juga menjadi alat guru untuk memotivasi siswa agar mereka dapat menjadi pribadi yang baik sesuai dengan para tokoh dan agar mereka dapat menjadi teladan seperti para tokoh. Hal tersebut sesuai dengan paparan dari Atika Fitria dan Eka Yanuarti bahwa strategi ini dapat dilakukan dengan menceritakan pada siswa tentang kisah-kisah agung dari tokoh-tokoh spiritual, upaya ini merupakan komunikasi universal yang mampu dimanfaatkan guru pendidikan agama islam untuk membina kecerdasan spiritual siswa melalui petikan hikmah jalan hidup seorang tokoh panutan seperti kisah para Nabi dan Rasul, dan lain-lain (Fitria dan Eka Yanuarti, 2018: 179-189).

Dengan demikian maka startegi ini efektif dalam memberikan pembinaan kecerdasan spiritual bagi siswa. Dengan ini siswa dapat merubah hidup mereka dengan mencontoh dari kisah para tokoh yang telah diceritakan. Dengan bercerita ini menjadi solusi bagi guru untuk membina kecerdasan spiritual siswa, sehingga lebih mudah memberikan dorongan untuk anak dalam menerima pembinaan kecerdasan spiritual.

\section{Mengajak Siswa Berdiskusi dalam Berbagai Persoalan dengan Perspektif Rubaniah}

Memberikan kesempatan bagi siswa menyampaikan pendapatnya melalui diskusi merupakan hak siswa dalam kegiatan pembelajaran, baik diskusi pribadi ataupun diskusi kelompok yang ada di kelas. Dari berbagai hasil observasi dan wawancara dengan narasumber yaitu Guru PAI SD N Juragan didapat keterangan bahwa kegiatan diskusi yang dilakukan guru ini menjadi kesempatan guru untuk lebih dekat dengan peserta didik secara individual. Guru 
mencoba memberikan solusi dengan mengajak mereka berdiskusi secara pribadi sehingga anak merasa lebih nyaman ketika berdiskusi. Untuk kegiatan diskusi selain membahas masalah pribadi ada pula diskusi dalam kelas atau bisa dikatakan literasi dalam hal ruaniah, guru mengajak siswa membahas suatu permasalahan dan meminta siswa untuk memberikan pendapat meraka melalui pespektif ruhaniah. Dengan kata lain ini dapat membina kecerdasan spiritual mereka secara mendalam. Hal ini sesuai dengan ungkapan Atika Fitria dan Eka Yanuarti, yang menyampaikan bahwa dengan mengajak siswa berdiskusi dalam berbagai persoalan dengan perspektif ruhaniah, guru mampu memberikan pemahaman kepada siswa untuk lebih bijak dalam menyikapi suatu persoalan, agar mereka bisa terhindar dari perbuatan yang terlarang dalam agama(Fitria dan Eka Yanuarti, 2018: 179-189).

Dengan ini, kegiatan diskusi yang dilakukan guru dapat memberikan pencerahan bagi siswa untuk menyampaikan pemikiran-pemikiran yang ingin diungkapkan siswa. Mereka merasa diperhatikan oleh guru, karena setelah mereka mengungkapkan pendapat, kemudian mendapat jawaban atau respon seperti ini merupakan salah satu bentuk apresiasi bagi siswa. Dan sebagai guru harus mampu memberikan kesempatan diskusi bagi semua siswa agar tidak menimbulkan kecemburuan sosial dan mengajarkan anak-anak lebih menghargai pendapat orang lain. Alhasil pembinaan kecerdasan spiritual berjalan dengan baik.

\section{Mengajak Siswa Berkunjung ke Tempat-tempat Orang Sakit dan Berta'riah}

Hubungan antara manusia dengan manusia merupakan hal wajar di kehidupan ini, dengan saling berhubungan akan memunculkan rasa kasih sayang. Dalam hal ini seorang guru berusaha untuk memunculkan rasa tidak hanya kasih sayang dalam diri siswa melinkan seperti rasa simpati, empati dan perhatian. Dengan mengajak siswa berkujung ke tempat-tempat orang sakit dan bertz'ziah diharapkan mampu menumbuhkan rasa yang telah disebutkan diatas. Dari observasi dan wawancara dengan 
narasumber yaitu Guru PAI SD N Juragan diperoleh hasil bahwa ketika guru mengajak siswa berkunjung ke tempat orang sakit dan berta'ziah merupakan cara guru menunjukan kepada meraka tentang kesusahan yang di alami orang lain sehingga akan memunculkan rasa simpati dan rasa syukur pada diri siswa. Mereka akan cenderung lebih bisa menghargai keadaan baik ataupun buruk yang mereka hadapi, ketika dalam keadaan buruk mereka akan tersadar bahwa ada keadaan yang lebih buruk dari mereka. Strategi ini sesuai dengan pendapat Atika Fitria dan Eka Yanuarti bahwa mengajak siswa kunjungan ke tempat-tempat orang sakit dan berta'ziah, dengan melakukan kunjungan seperti ini diharapkan siswa bisa memaknai dan mensyukuri nikmat yang diberikan oleh Allah SWT kepada mereka (Fitria dan Eka Yanuarti, 2018: 179189). Dengan kata lain, pemilihan strategi yang tepat ini merupakan bentuk pembinaan kecerdasan spiritual yang baik. Hal ini dapat menunjukan secara langsung kepada siswa keadaan orang lain yang kesusahan dan dengan mudah menyetuh hati mereka untuk dapat lebih mensyukuri apa yang telah mereka miliki saat ini. Pembinaan kecerdasan spiritual dengan cara ini dapat diserap siswa dengan mudah.

\section{Melibatkan Siswa dalam Kegiatan Keagamaan}

Melibatkan siswa dalam berbagai kegiatan keagamaan merupakan langkah tepat sasaran seorang guru dalam membina kecerdasan spiritual, dalam melibatkan siswa akan lebih mudah membina kecerdasan spritual sebab diketahui bahwa kecerdasann spritual banyak bagian dari keagamaan. Diperoleh dari observasi dan wawancara dengan narasumber yaitu Guru PAI SD N Juragan saat guru mengikutsertakan siswa dalam kegiatan keagamaan banyak mencerminkan sifat kecerdasan spiritual, mulai dari kegiatan sholat-sholat yang dijadwalkan, kegiatan peringatan hari besar Islam, kegiatan keagamaan yang dibuat sendiri oleh sekolah. Kegiatan ini memberikan pembinaan kecerdasan spiritual kepada siswa secara mendalam. Keterlibatan anak-anak dalam kegiatan keagamaan akan menumbuhkan rasa tanggung jawab dan 
kewajiban dalam agamanya. Hal ini sejalan dengan pendapat Atika Fitria dan Eka Yanuarti bahwa melibatkan siswa dalam kegiatan keagamaan, maka siswa akan didorong aktif mengerjakan berbagai kegiatan sehingga pekerjaan guru hanya sebagai fasilitator dan motivator siswa agar lebih disiplin melaksanakan ibadah atau kegiatan-kegiatan keagamaan lainnya. Dengan cara ini, siswa akan mudah dan cepat memahami tujuan dari kegiatan yang dilaksanakan itu, sehingga pembelajaran yang ia dapatkan akan bernar-bernar tertanam dalam diri siswa (Fitria dan Eka Yanuarti, 2018: 179-189).

Oleh sebab itu, pembinaan kecerdasan spiritual siswa dilakukan dengan melibatkan siswa dalam kegiatan keagamaan sangat efektif. Siswa menjadi lebih perhatian dengan kegiatan keagamaan dari pada sebelumnya, anak-anak lebih mudah menerima kegiatan keagamaan dengan rasa senang dan ikhlas. Siswa menjadi lebih dekat dengan Tuhan dan lebih merasa adanya keterlibatan diri mereka dengan agama.

\section{Mengikutsertakan Siswa dalam Kegiatan-kegiatan Sosial}

Strategi ini dilakukan dalam rangka meraih perhatian siswa dalam kehidupan sosial mereka, sehingga mereka dapat berhubungan baik dengan sesama manusia ataupun lainnnya. Mereka lebih mamahami sebuah arti kebersamaan dan gotong royong. Hasil dari observasi dan wawancara dengan narasumber yaitu Guru PAI SD N Juragan bahwa dengan kegiatan ini guru mencoba memberikan peluang bagi siswa untuk menyesuaikan kehidupan manusia yang saling bersosialisasi. Dengan kegiatan sosial di sekolah yang melibatkan anak-anak dari seluruh kelas maka anak-anak akan beradaptasi dengan kegiatan yang melibatkan banyak orang. Guru berusaha mengajarkan anak bahwa hubungan kehidupan ini melibatkan antara manusia dengan Allah SW'T, manusia dengan mannusia, manusia dengan makhluknya. Seperti halnya ungkapan dari Atika Fitria dan Eka Yanuarti bahwa mengikutsertakan siswa dalam kegiatan sosial bertujuan agar siswa mengerti sebuah kerbersamaan, kesetiakawanan, kepedulian 
terhadap sesama sebagai makhluk ciptaan-Nya (Fitria dan Eka Yanuarti, 2018: 179-189).

Maka berdasarkan hal tersebut, pembinaan kecerdasan spiritual yang dilakukan dengan megikutsertakan siswa dalam kegiatan sosial menjadi cara yang tepat oleh guru untuk melatih anak-anak agar memiliki jiwa sosial dengan melibatkan Tuhan didalamnya. Hal ini dikarenakan meraka diajarkan untuk menghargai sesama manusia dan makhluk ciptaan-Nya, hingga akhirnya anak-anak akan merasa lebih nyaman dengan lingkungannya.

\section{Mengajak Siswa Melihat Keindahan Alam}

Menikmati keindahan alam dapat menyegarkan fikiran dengan melibatkan Tuhan didalamnya, manusia diajarkan untuk mensyukuri keindaan alam yang telah Allah SWT ciptakan bagi hambanya. Kegiatan ini akan mampu mencerahkan pemikiran para siswa tentang ciptaan-Nya. Sesuai hasil observasi dan wawancara dengan narasumber yaitu Guru PAI SD N Juragan bahwa kegiatan mengajak anak-anak menikmati keindahan alam dapat menjadi sumber inspirasi bagi guru untuk menerapkan rasa syukur kepada para siswa. Dengan melibatkan siswa menikmati alam seraya memberikan pemahaman kepada mereka tentang ciptaan-Nya, anak-anak akan lebih mudah menerima ungkapan guru mengenai bentuk rasa syukur karena diperlihatkan langsung dengan alam. Hal ini senada dengan Atika Fitria dan Eka Yanuarti yang mengungkapkan bahwa dengan adanya kegiatan ini diharapkan siswa lebih memahami tentang pencipta-Nya, dan akan mampu membawa mereka untuk selalu bersyukur atas nikmat dan karunia yang dititipkan oleh Allah SWT kepada mereka (Fitria dan Eka Yanuarti, 2018: 179-189).

Dengan begitu, pembinaan kecerdasan spiritual dengan mengajak siswa melihat keindahan alam merupakan langkah yang menyenangkan dan mudah bagi guru. Sebab dalam melakukan kegiatan ini anak-anak tampak lebih bersemangat ketika mengikuti pelajaran. Yang biasanya kegiatan pembelajaran dilakukan di dalam kelas kini beralih di luar kelas dan menyenangkan bagi siswa. 
Dengan demikian akhirnya anak lebih merasa segar dan mudah menerima ajaran guru.

\section{Catatan Akhir}

Adanya uraian analisis dari bab I sampai dengan bab IV, garis besar kesimpulan dari skirpsi ini, yaitu: Strategi yang dilakukan guru PAI dalam membina kecerdasan spiritual siswa kelas IV SD N Juragan Kandeman mulai dari kurikulum tersembunyi sampai mengajak siswa menikmati keindahan alam berjalan dengan baik dan efektif, dimana anak-anak lebih mampu dan terbiasa menerima bimbingan kecerdasan spiritual sesuai dengan ajaraan Islam. Siswa mulai mencerminkan kecerdasan spiritual yang telah terbina, di mana mereka lebih termotivasi giat belajar, sopan dan santun terhadap guru dalam bertuturkata, menyayangi teman, menyukai tadarus, saling tolong menolong, lebih menghargai orang lain, lebih bersyukur dan rajin mengaji, menghargai lingkungan, dan lebih mengakui ciptaan Tuhan. Faktor pendukung yang dialami guru PAI dalam membina kecerdasan spiritual siswa kelas IV SD N Juragan Kandeman adalah dukungan dari lingkungan keluarga, lingkungan masyarakat, dan teman sebaya. Kemudian untuk fakor penghambatnya juga berasal dari lingkungan keluarga, lingkungan masyarakat, dan teman sebaya. Dengan demikian strategi yang dilakukan guru PAI dalam membina kecerdasan spiritual siswa kelas IV SD N Juragan telah cukup baik. Hanya perlu di pertahankan dan ditingkatkan agar memperoleh hasil maksimal dan mencapai tujuan yang lebih baik. Berdasarkan permasalahan yang telah dibahas peneliti mengenai strategi guru PAI dalam membina kecerdasan spiritual siswa kelas IV SD N Juragan Kandeman. Maka peneliti dengan ini ingin menyampaikan saran Yaitu sebagai berikut: Bagi guru diharapkan agar guru dapat lebih mengoptimalkan strategi-strategi yang telah dilakukan agar siswa merasa nyaman ketika menerima pelajaran dalam pembinaan kecerdasan spiritual. Bagi lembaga peneliti berharap dari pihak sekolah memberi dukungan dalam pelaksanaan strategi guru PAI dalam membina kecerdasan spiritual siswa, baik dukungan secara 
materiil atau non materiil. Selain itu diharapkan agar sekolah melakukan pelatihan-pelatihan kepada guru guna meningkatkan kecakapan dalam mengajar serta mempertahankan profesionalitas mereka. Bagi siswa peneliti berharap seluruh siswa SD N Juragan khususnya kelas IV, dapat mengikuti pendidikan yang diajarkan oleh guru dengan baik dan benar. Tanamkan pada diri kalian untuk memotivasi diri kalian sendiri karen itu merupakan pintu bagi kalian untuk lebih mudah menerima motivasi dari pihak lain yang memberikan semangat bagi kalian untuk menjadi siswa yang memilki kecerdasan spiriual yang luar biasa dan berkakhlakul karimah serta berguna bagi nusa dan bangsa.

\section{Daftar Pustaka}

Achmadi. 2005. Ideologi Pedidikan Islam. Yogyakarta: Pustaka pelajar Arifin, H.M. 1996. Ilmu Pendidikan Islam: suatu tinjauan teoritis dan praktis berdasarkan pendekatan interdisipliner. Jakarta: Bumi Aksara.

Arikunto, Suharsimi. 2003. Prosedur Penelitian Suatu Pendekatan Praktek. Jakarta: renika Cipta

Arikunto, Suharsimi. 2005. Manajemen Pendidikan. Jakarta: Renika Cipta

Azwar, Saifuddin. 1999. Metode Penelitian Kualitatif. Yogyakarta: Pustaka Pelajar

Azzet, Akhmad Muhaimin. 2013. Mengembangkan Kecerdasan Spiritual Bagi Anak. Yogyakarta: Kata Hati

Danim, Sudarwan. 2002. Menjadi Peneliti Kualitatif. Bandung: Pustaka Setia.

Desmita. 2010. Psikologi Perkembangan Peserta Didik. Bandung: Pt. Remaja Rosdakarya.

Djamarah, Syaiful Bahri. 2000. Guru dan Anak Didik dalam Interaksi Edukatif. Jakarta: Renika Cipta

Efendi, Agus. 2005. Revolusi Kecerdasan Abad 21. Bandung: Alfa Beta Faisal, Sanapiah. 2010. Format-format Penelitian Sosial: dasar-dasar dan aplikasi. Jakarta: Raja Grafindo Persada 
Fitria, Atika dan Eka Yanuarti. 2018. "Upaya Guru Pendidikan Agama Islam Dalam Menumbuhkan Kecerdasan Spiritual Siswa", (IAIN Curup- bengkulu: Belajea Jurnal Pendidikan Islam no. 02. vol. 3

Ghony, M. Djunaidi dan Fauzan Almanshur. 2012. Metode Penelitian Kualitatif. Yogyakarta: Ar-Ruzz Media

Ibung, Dian. 2009. Mengembangkan Nilai Moral pada Anak. Jakarta: Alex Media Komputindo

Kurniasih, Imas. 2010. Mendidik SQ Anak menurut Nabi Mubammad $S A W$. Jakarta: Suka Buku

Moleong, Lexy J. 2006. Metodologi Penelitian Kualitatif. Bandung:

Remaja Rosdakarya

Mustakim, Zaenal. 2011. Strategi Metode dan Pembelajaran. Pekalongan: STAIN PRESS

Pasiak, Taufik. 2003. Revolusi IQ/EQ/SQ Antara Neurosains dan AlQur'an. Bandung: Mizan Pustaka

Prawira, Purwa atmaja. 2013. Psikologi Pendidikan dalam Perspektif Baru cet, ke. 1. Jogjakarta: Ar-Ruzz Media

Ramayulis. 2008. Ilmu Pendidikan Islam. Jakarta: Kalam Mulia

Safaria, Triantoro. 2007. Spiritual Intelegence: Metode Pengembangan Kecerdasan Spiritual Anak. Yogyakarta: Graha Ilmu

Saleh, Abdul Rahman dan Muhbib Abdul Wahab. 2004. Psikologi Pengantar dalam Perspektif Islam. Jakarta: Prenada Media

Sangadji, Etta Mamang dan Sopiah. 2010. Metodologi Penelitian: Pendekatan Praktis dalam Penelitian. Yogyakarta: Andi Offset

Siregar, Masarudin. 2000. Pengelolaan Pengajaran. Yogyakarta: Pustaka Pelajar

Siswanto, Wahyudi dkk. 2010. Membentuk Kecerdasan Spiritual Anak:

Pedoman Penting Bagi Orang Tua dalam Mendidik. Anak. Jakarta: Amzah

Sugiyono. 2014. Metode Penelitian Kuantitatif dan Kualitatif dan R\&D. Bandung Alfabeta

Tafsir, Ahmad. 2001. Ilmu Pendidikan Dalam Perspektif Islam. Bandung: Remaja Rosdakarya 
el-HiKMAH, Vol. 13, No. 2, Desember 2019

Tasmara, Toto. 2001. Kecerdasan Rohaniyah Transcedental Intelegence. Jakarta: Gema Isani Press

Undang-undang Republik Indonesia No. 14 Tahun 2005 tentang Guru dan Dosen. Jakarta: Sinar Grafika

Undang-undang Republik Indonesia No. 20 Tahun 2003 tentang Sistem Pendidikan Nasional. Jakarta: Transmedia Pustaka 